\title{
CASE OF ACHOLURIC JAUNDICE.
}

\author{
By LEONARD FINDLAY, M.D., R. H. DOBBS, B.Ch., and N. SMITH. \\ (From the Princess Elizabeth of York Hospital for Children, London.)
}

The following case seems worthy of record not only because of the comparative rarity of the condition but also on account of the circumstances in which it came under observation. Moreover it has the further interest in that it raises certain points of fundamental importance in connection with the origin and mode of transmission of the disease.

The patient, a boy aged $4 \frac{1}{2}$ years, was admitted to the Princess Elizabeth of York Hospital for Children on 2I.5.34 with a history of "feeling cold and weak" of 7 days' duration.

Family History.-The father, aged 40 years, was alive and well and the mother (who brought the child to hospital) was aged 46 years. She stated that she had never been strong and as a child was considered anæmic: but there was no history of jaundice and she had never been " laid up." There were two other children in the family; the eldest, a boy of I2 years, had had rheumatic fever and chorea; the other child, a boy aged 9 years, had always enjoyed good health.

Previous Health.-The patient was a healthy baby born after a normal delivery, was breast fed for 2 months, cut his first teeth at 6 months, walked at I4 months and talked at I8 months. With the exception of measles at the age of 2 years he had always enjoyed good health until the onset of the present illness.

Present Illness.-One week before admission he began, apparently quite suddenly, to complain of feeling cold and seemed disinclined to run about. Next day he vomited twice and was fevered, and since then his weakness rapidly increased in severity.

On admission to hospital he appeared very ill; he was exceedingly anæmic, the mucous membranes of the lips being specially pale. $\mathrm{He}$ was quite well ${ }^{\circ}$ developed and well nourished (weight $30 \mathrm{lbs}$. Io ozs. and height $39 \frac{1}{2}$ ins.) The temperature was $100^{\circ} \mathrm{F}$. and the pulse rate I4O per minute. The skin of the abdomen and legs had a slightly yellowish tint but there was no marked icterus and the conjunctivæ were clear. There were no petechiæ. The glands in both anterior cervical triangles were moderately enlarged.

The tongue was clean and moist but in places showed desquamation of epithelium producing the so-called geographical appearance. A few of the teeth were carious and there was an abscess at the root of the first lower right pre-molar. The tonsils were moderately enlarged but not septic.

The heart and lungs presented no abnormality except for a basal ventricular systolic murmur.

The abdomen was lax, devoid of tenderness, with no enlargement of the liver or spleen.

The nervous system presented no abnormality.

The urine which was dark in colour was negative for urobilin; it contained a trace of acetone but no albumin, blood or sugar.

Blood Examination:-Hb. 20\%.

Red corpuscles $\mathrm{I}, 600,000$ per c.mm.

Leucocytes

37,000 ", ,

Stained films revealed variation in size and shape, many small forms being present. (Dr. Janet Vaughan kindly estimated the size of the red cells and 
reported megalocytes I\% and microcytes $29 \%$.) Nucleated red blood corpuscles were numerous, I4 megaloblasts and ro normoblasts being observed while counting I00 white cells.

Differential count of leucocytes :-

\begin{tabular}{llllllr} 
Neut. Polymorphs & $\ldots$ & $\ldots$ & $\ldots$ & $\ldots$ & $59 \%$ \\
\multicolumn{1}{c}{ Myelocytes } & & $\ldots$ & $\ldots$ & $\ldots$ & $\ldots$ & $6 \%$ \\
Myeloblasts & $\ldots$ & $\ldots$ & $\ldots$ & $\ldots$ & $\ldots$ & $2 \%$ \\
Lymphocytes & $\ldots$ & $\ldots$ & $\ldots$ & $\ldots$ & $\ldots$ & $20 \%$ \\
Monocytes $\ldots$ & $\ldots$ & $\ldots$ & $\ldots$ & $\ldots$ & $\ldots$ & $8 \%$ \\
Eosinophiles & $\ldots$ & $\ldots$ & $\ldots$ & $\ldots$ & $\ldots$ & $4 \%$ \\
Basophiles & $\ldots$ & $\ldots$ & $\ldots$ & $\ldots$ & $\ldots$ & $1 \%$
\end{tabular}

Van den Bergh reaction:-Delayed direct and indirect positive.

Fragility of red cells :- Hæmolysis commenced with $.42 \%$ saline in comparison with $.38 \%$ in the case of a control blood examined simultaneously.

It was quite apparent that we had to deal with an acute hæmolytic anæmia as revealed by the presence of urobilin in the blood serum (positive delayed direct and indirect van den Bergh) and it was surmised that this was of the hereditary type because of the microcytosis and the slightly increased fragility of the red cells even although there was no history of some other member of the family being similarly affected. It had of course to be admitted that the degree of the lessened resistance of the red cells did not reach the degree usually met with in this disease, but it was definitely in excess of the normal control, and one suspected that perhaps the dilution of the saline solution employed had not been sufficiently accurate and therefore, before coming to any definite decision, the test would require to be repeated. The question of the condition being an example of spontaneous hæmolytic anæmia of Lederer type, and perhaps dependent on the septic focus at the root of the tooth, had, however, to be borne in mind.

By the day after admission the boy seemed a little easier. The temperature remained slightly elevated $\left(99^{\circ}-100.4^{\circ} \mathrm{F}\right.$.) for the first twenty-four hours but thereafter declined to normal.

Three days after admission (24.5.34) he was definitely improved; he was more lively and the lips and cheeks seemed redder and the yellowish tint of the skin was less intense. The septic focus at the root of the tooth was subsiding and the tongue was becoming more normal in appearance. Examination of the blood, however, showed little change:-Hb. $22 \%$; red cells $\mathrm{I}, 640,000$ and leucocytes 38,000 per c.mm.; stained films still revealed numerous nucleated red cells, I2 megaloblasts and 36 normoblasts for every Ioo white cells. Fragility of red cells (repeated) :Hæmolysis commenced with $.6 \%$ saline whereas in control blood this only occurred with $.42 \%$ saline.

In view of the above repeated fragility test there seemed little doubt that the condition was, as at first suspected, one of so-called acholuric jaundice. As this disease is markedly familial in its incidence, it was decided to make more particular enquiry into the family history and especially to investigate the fragility of the red cells in all the other members of the family. On communicating with the parents the father arrived at the hospital and said that his wife could not come and bring the children as she had been taken very ill. It seemed that some few days after she had brought her youngest child (our patient) to hospital she herself became very weak, fainted whenever she stood up and had to remain in bed. On 30.5.34 she was visited by Drs. Dobbs and Mackinney (R.M.O. and House Physician at Shadwell), when she was found extremely anæmic with a yellowish 
tint of the skin and a spleen that was just palpable. Examination of the blood gave the following result:-

$\begin{array}{lll}\mathrm{Hb} . \ldots & \ldots & 25 \% \\ \mathrm{Red} \text { cells } & \ldots & 2, \mathrm{I} 50,000 \text { per c.mm. }\end{array}$

Leucocytes ... 20,000 " (neut. polys. 7x\%, lymphocytes $18 \%$, monocytes $4 \%$, eosinophiles $2 \%$, basophiles I\%). 3 megaloblasts were observed while counting 300 white cells.

Van den Bergh reaction: Direct delayed positive.

Fragility of red cells: Hæmolysis commenced with $.6 \%$ saline as compared with $.4 \%$ in a normal control.

The above incident made it quite clear that our patient was suffering from inherited hæmolytic icterus (acholuric jaundice) which had been transmitted by his mother. Curiously, however, he had developed active manifestations before she did, although it must be remembered that it had been reported that as a child she had been considered anæmic.

Since it would be unlikely that the mother and son would be the sole members affected, all the available maternal relatives were investigated so far as the fragility of the red cells was concerned, although there was no history of any of them ever having suffered from suspicious symptoms. This investigation included the two other children in the family, the mother's father and mother and the mother's only sister. The father of the child was also examined hæmatologically. The results, which were negative in each instance, are shown below:-

TABLE I.

Fragility of Red Cells in Patient and Relatives.

DATE.

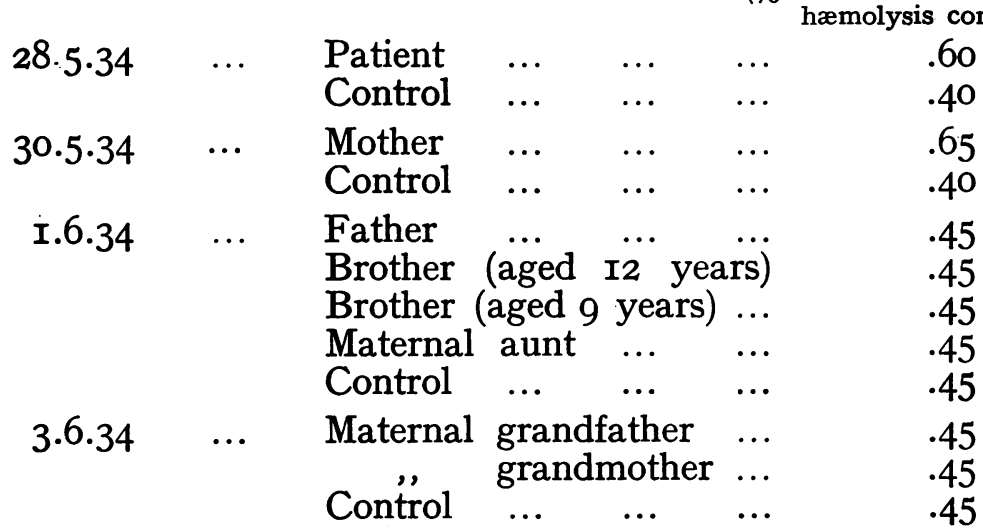

RESULT.

(\% of saline solution with which

60

.65

40

.45

45

45

.45

.45

.45

45

Course of illness.-By the end of the first week of residence (28.5.34) there was considerable improvement and that, it may be noted, without any medicinal measures being adopted. He was indeed a different child - better colour, brighter, taking his food well and sleeping well, all of which improvement was reflected in the condition of the blood as shown below:-

$\mathrm{Hb}$. $53 \%$

Red cells ... 2,680,000 per c.mm.

Leucocytes ... I4,000 ", (neut. polys. 53\%, neut. myel, I\%, lymphocytes $35 \%$, monocytes $7 \%$ and eosinophiles $2 \%$ ). 7 megaloblasts and $2 \mathrm{I}$ normoblasts for every IOO leucocytes. Reticulocytes numbered I9.I\%. 
The improvement of the first week was maintained so that by the end of 7 weeks he appeared an absolutely normal boy. It may be remarked that he was never transfused, and that he received no medicinal treatment for the anæmia. Since, however, there remained the probability of a recurrence of the hæmolytic attack (blood crisis), splenectomy was decided upon and this was carried out on I7.7.34, i.e., 8 weeks after coming under observation. At this time there was no evidence of anæmia, although it should be recorded that the reticulocyte count was $6.0 \%$ instead of the normal $\mathrm{I} \%$ which suggests that the blood forming apparatus was acting under some strain (see Table 2). Unfortunately, at the time, no particular attention was paid to this fact, since it probably explains to some extent the development of the attack of anæmia following the operation.

Splenectomy was performed by Mr. Acton Davis without any difficulty and with comparatively little loss of blood. The patient seemed to stand the operation well. On the following day, however, the boy appeared very ill. He was pale, with slight fever, and there was considerable epistaxis. Examination of the blood revealed a drop in both hæmoglobin and red cells with a definite leucocytosis; the reticulocytes rose to $I 5 \%$ but no nucleated red blood corpuscles were observed and the van den Bergh reaction, both direct and indirect, were negative. At first it was thought that this was another blood crisis, and by a coincidence had commenced just at the time of the operation, but the negative van den Bergh reaction, showing the absence of hæmolysis (which is the characteristic feature of such attacks), points rather to some other explanation, as e.g., loss of blood. The absence of nucleated red cells is also against the view that the condition was of the nature of a blood crisis. Whatever be the explanation, the attack was quickly recovered from and when the boy was last seen (13.9.34) he appeared in perfect health. He had a good colour, was bright and cheery, was taking his food well and he was full of energy. The course of events is well seen in the table of periodic blood counts (Table 2):-

\section{TABLE 2.}

Periodic Blood Examinations in Case of Acholuric Jaundice.

\begin{tabular}{|c|c|c|c|c|c|c|c|c|}
\hline Date. & & $\mathrm{Hb}$. & & Red Cells. & & Leucocytes. & & iculocytes \% \\
\hline $22.5 \cdot 34$ & $\ldots$ & 20 & $\ldots$ & $I, 600,000$ & $\ldots$ & 37,000 & $\ldots$ & - \\
\hline $24 \cdot 5 \cdot 34$ & $\ldots$ & 22 & $\ldots$ & $I, 600,000$ & $\ldots$ & 38,000 & $\ldots$ & I8 \\
\hline $28.5 \cdot 34$ & $\ldots$ & 53 & $\ldots$ & $2,680,000$ & $\ldots$ & I4,000 & $\ldots$ & Ig.I \\
\hline $3 I .5 \cdot 34$ & $\ldots$ & 70 & $\ldots$ & $3,6 \mathrm{ro}, 000$ & $\ldots$ & 6,500 & $\ldots$ & I6.4 \\
\hline 4.6 .34 & $\ldots$ & 76 & $\ldots$ & $3,900,000$ & $\ldots$ & 8,000 & $\ldots$ & 8.2 \\
\hline I2.6.34 & $\ldots$ & 82 & $\ldots$ & $4,290,000$ & $\ldots$ & I0,000 & $\ldots$ & I2.0 \\
\hline 20.6 .34 & $\ldots$ & 82 & $\ldots$ & $4,400,000$ & $\ldots$ & 9,000 & $\ldots$ & 9.0 \\
\hline 28.6 .34 & $\ldots$ & 96 & $\ldots$ & $5,340,000$ & $\ldots$ & 14,000 & $\ldots$ & 8.0 \\
\hline$I 7 \cdot 7 \cdot 34$ & $\ldots$ & 92 & $\ldots$ & $\begin{array}{l}5,300,000 \\
\text { lenectomy }\end{array}$ & $\ldots$ & 9,000 & $\ldots$ & 6.0 \\
\hline I8.7.34 & $\ldots$ & 78 & $\ldots$ & $3,650,000$ & $\ldots$ & 24,000 & $\ldots$ & I5.0 \\
\hline $27 \cdot 7 \cdot 34$ & $\ldots$ & $8 I$ & $\ldots$ & $4, \mathrm{I} 30,000$ & $\ldots$ & 18,000 & $\ldots$ & 6.0 \\
\hline $30.7 \cdot 34$ & $\ldots$ & 82 & $\ldots$ & $4,320,000$ & $\ldots$ & - & $\ldots$ & - \\
\hline 8.8 .34 & $\ldots$ & 87 & $\ldots$ & $4,800,000$ & $\ldots$ & I2,000 & $\ldots$ & - \\
\hline I3.9.34 & $\ldots$ & 92 & $\ldots$ & $5,000,000$ & $\ldots$ & 8,500 & $\ldots$ & 0.3 \\
\hline
\end{tabular}


The spleen, which was much enlarged, revealed on histological examination some hypoplasia of the Malpighian bodies and distension of the sinuses filled with blood, which are the usual changes met with in this disease.

\section{Commentary.}

As a rule, in the case of the child, a history of some similar illness can be obtained in an older member of the family, in one of the parents or in some relative, but so far as could be learned our patient was the first member of the family to be attacked by active manifestations of the disease. It must, however, be remembered that the disease may be present in some other member of the family but has remained latent. By latent mischief is meant that the underlying predisposing cause of the blood destruction, viz. :-increased fragility of the red cells, is present although there is no symptomatic evidence of the defect. Indeed, the presence or absence of the disease can only be determined by an examination of the blood for the degree of resistance of the red cells, which is the pathognomomic feature of the malady. Consequently, no definite opinion regarding the nature of any suspected case can be come to until this examination has been carried out. It is the want of appreciation of this fact, and the failure to admit that increased fragility is an integral part of the disease, which is responsible for much of the confusion of opinion which exists on the matter.

Certain authors ${ }^{(1)}$ have stated that they have met with examples of acholuric jaundice in which the fragility of the red cells was normal. It might be pertinately asked on what grounds a diagnosis of acholuric jaundice was ever made in such cases for, as we have said, this is the pathognomomic feature of the condition. There are, of course, many varieties of anæmia in which hæmolysis occurs, but among these acholuric jaundice stands out by this characteristic peculiarity of the hæmatocytes. Pernicious anæmia, lead poisoning and malaria are all conditions in which hæmolysis is a prominent feature, but no one would suggest that this indicates any relationship with acholuric jaundice. In all of these varieties of anæmia the resistance of the red cells is normal, in fact it may be increased rather than diminished, a point which demarcates them sharply from the special type we are considering.

Equally characteristic with the increased fragility of the red cells is the familial tendency of the disease. From a review of the literature no more striking fact emerges than that the more thorough the investigation of the case and the relatives the more constant is this combination of increased fragility and hereditary transmission. Indeed, it may almost be laid down as an axiom that the one feature is never present without the other. And, just as neglect of considering increased fragility of the red cells as an essential criterion of the disease leads to mistakes in diagnosis, so the want of appreciation that this may be the sole evidence of the malady has been responsible for the view that it is not invariably hereditary but on occasion may be acquired in nature. In many of the recorded examples ${ }^{(2,3}$ \& 4) of so-called acquired acholuric jaundice the authors have either not paid attention to this point and have contented themselves with a negative history of active manifestations or, owing to death of the parents and collaterals, a blood examination 
was not possible. In other instances the patient was unmarried, or too young to have progeny, so that there was no opportunity of demonstrating whether the defect could be transmitted. In the case of our own observations one can understand how by a different sequence of events an erroneous opinion regarding the hereditary nature of the disease might have arisen. If the mother had not taken ill and her blood been examined, the boy would have been an isolated example of the disease in the family and his age would preclude a demonstration of its transmission, or again, if the mother had developed her acute attack before the birth of her third child (i.e., our patient) then even with the most thorough investigation she would have been the only affected member of this particular stock and a diagnosis of acquired acholuric jaundice might have been suggested but which subsequent events would have shown to be wrong, because acquired characters cannot be transmitted. It is thus apparent how difficulties and dangers of formulating an opinion on the important matter of heredity may arise.

The majority of writers, however, do admit that the disease is hereditary, but there is no consensus of opinion among them regarding the method of its transmission. According to Campbell and Warner ${ }^{(5)}$ the underlying defect in the red blood corpuscle is transmitted as a dominant character by the law of Mendel. These authors came to this conclusion because in their experience the disease was transmitted invariably from parent to child. Our case history is, however, against this view for, although the child's mother was similarly affected, neither of her parents gave any history of having suffered from any suspicious symptoms and in both the fragility of the red cells was normal. It might be suggested to account for this occurrence that the mother of our patient was an illegitimate child, but delicate enquiry lent no support to such a suspicion. It might also be suggested that owing to the age of the grandparents, who were aged 73 and 77 years respectively, the undue fragility of the red cells had disappeared, but we know of no facts to support such a contention. But as Meulengarst ${ }^{(6)}$ and Vaughan ${ }^{(7)}$ also record a similar happening in an equally thoroughly investigated family our example is not an isolated event. It would seem therefore more likely that the defect is of the nature of a recessive character in which case its transmission would be less constant and by apparently healthy individuals quite understandable. On the other hand, it may be that the condition is dependent on a particular grouping of the chromosomes in the germ cell (so-called mutation). This would make its transmission in any one stock most erratic and thus render the elimination of heredity as a factor of etiological importance a most difficult problem.

Splenomegaly is another characteristic feature of this disease and its presence should always suggest an examination of the behaviour of the red blood corpuscles against hypotonic saline in case the condition may be in the so-called latent state. Enlargement of the organ, however, is not invariable. According to Janet Vaughan no enlargement of the spleen is noted in 20 per cent. of cases. In our own patient there was never at any time any enlargement of the organ, and during the height of the mother's acute attack the spleen was only just palpable.

One interesting point in the disease is the cause of the acute hæmolytic attacks. It is quite clear from the number of so-called latent examples which have been 
observed that there must be some factor in addition to the diminished resistance of the red cells. It has been suggested that at the time of the crisis the red cells are specially vulnerable, but there seems little justification for such a view since the fragility as tested by hypotonic saline solutions is not specially increased at these times. In fact, as in not a few recorded in the literature, the estimated degree of resistance of the red cells may be greater during the crisis than it is after recovery. Septic conditions, splenic abnormalities and subtle metabolic changes have all been blamed, but as a rule no exciting moment can be discovered, the attacks coming on without any apparent cause. Janet Vaughan ${ }^{(8)}$ has recorded hæmolytic crises occurring simultaneously in a father and son which would point to some common external agent, perhaps of the nature of a psychic shock, a chill or an infection like influenza. In our family it might be suggested that the septic focus at the root of the tooth was responsible in the case of the child, and one might wonder if anxiety over her boy's illness had precipitated the attack in the mother. Whatever be the explanation, it would seem in some way to be associated with the spleen, since removal of this organ disposes of all liability to a recurrence of the attacks. One of the functions of the spleen is to destroy effete red cells, and it would appear that in some way its activity at these times is increased or, as Parkes Weber $^{(9)}$ expresses it, there develops a state of hypersplenism.

It was noted in our case report that the patient was submitted to splenectomy, and it is interesting to record that a similar operation was performed on his mother who had been admitted to the London Hospital. That this treatment should have been carried out independently and almost simultaneously in these two patients, and after the occurrence of only one hæmolytic crisis in each case, speaks for the confidence which this therapeutic measure enjoys in this disease. It is a confidence, too, which is amply justified for it is questionable if in undoubted acholuric jaundice a recurrence of hæmolysis has ever taken place after this operation. That splenectomy should be so eminently successful is nevertheless somewhat remarkable, since the operation would seem to have little or no effect on the fragility of the red cells. This, however, only accentuates, as we have already remarked, that although this peculiar defect in the red blood corpuscle is an essential condition for the production of hæmolysis, the spleen in some way plays an important rôle, but in exactly what manner it is at present impossible to say. Some authors have stated that they have observed a definite decrease in fragility after splenectomy but, on the other hand, many record an increase after the operation. In our own experience there has never resulted any radical change in the degree of resistance of the red cells after splenectomy, and any differences observed seemed no more than could be accounted for by variations in the concentration and reaction of the saline dilutions employed. That this is almost certainly true is revealed by the fact that the normal control bloods examined at the same times usually presented the same differences in degree of fragility. It is for this reason, and because of the great difficulty of always being certain of the exact concentration and reaction of the saline solution, that we deprecate the not uncommon practice of recording only the concentration of the saline in which the suspected blood showed the first traces of hæmolysis and omitting to mention what happened in the case of a normal control blood, if such were, and as should always be, examined simultaneously. The results of the simultaneous examination of the blood of the boy (our patient) and his mother and of the controls, before and after splenectomy, 
are given in the following table, and would seem to lend support to the above thesis:-

\title{
TABLE 3.
}

Fragility of Red Cells before and after Splenectomy.
DATE.
CHILD. $\quad$ conTROL. MOTHER. CoNTROL.

$\begin{array}{rcccccll}23.5 .34 & \ldots & .42 & \ldots & .38 & & & \\ 25.5 .34 & \ldots & .6 & \ldots & .4 & & .65 & \ldots \\ 30.5 .34 & . . & . & \ldots & - & \ldots & .65 & .4 \\ 31.5 .34 & \ldots & .6 & \ldots & .4 & & & \\ 20.6 .34 & \ldots & .6 & \ldots & .4 & & \\ 28.6 .34 & \ldots & .65 & \ldots & .45 & & \\ 5.7 .34 & \ldots & & & & \\ \text { I7.7.34 } & \ldots & .65 & \ldots & .45 & & \end{array}$

$\begin{array}{lllllllll}31.7 .34 & \ldots & .65 & \ldots & .45 & & & & \\ 13.9 .34 & \ldots & .65 & \ldots & .45 & & & & \\ 25.9 .34 & \ldots & - & \ldots & -62 & \ldots & .62 & \ldots & .44\end{array}$

\footnotetext{
(1) Parson, L. G., Arch. Dis. Child., 1933, vili, 209.

(2) Parkes Weber, F., Pro. Roy. Soc. Med., 1930, XXiv, (Clin.

(4) Mavidson, L. S. P.̈ Quart. Jour. Med., 1932, N.S. 1, 1943. Ikterus, Leipzig, 1922, p. 204.

(5) Campbell, J. M. H., and Warner, E. C., Quart. Jour. Med., 1926, xix, 333.

(6) Meulengarst, ibid, p. 192.

(7) Vaughan, J., The Ancemias, London, 1934, p. 184.

(8) Vaughan, J., ibid, p. 201.

(9) Parkes Weber, F., Brit. Med. Jour., 1929, 1, 766.
}

\section{OBSTRUCTIVE EMPHYSEMA DUE TO BRONCHIAL CARCINOMA.}

\author{
By H. V. MORLOCK, M.C., M.D., M.R.C.P.
}

(Physician, Miller General Hospital, City of London Hospital for Diseases of the Heart and Lungs, O.P. Department, Hampstead General Hospital.)

The patient, a man aged 46 years, presented himself with the following history: Six months previously, an unproductive cough had developed and had continued ever since. Three months later, pain appeared in the left chest, of a dull aching character, more or less continuous, which was increased on deep inspiration. There had been no hæmoptysis, nor had any loss of weight been noted.

Previous history revealed nothing of importance.

Condition on examination: Healthy looking man; face, mouth, throat, neck, presented nothing abnormal. No glands palpable in supraclaricular fossæ or axillæ. Heart, normal in size and position to palpation and percussion; sounds normal. Lungs: Left thorax a little fuller than right. Left moves less than right. Tactile fremitis diminished over left lung. On percussion, both lungs appeared equally resonant in all areas. On auscultation over right lung nothing abnormal heard. Over the whole of left lung, breath sounds completely absent. No bell sound, or succussion splash elicited.

These physical signs could be interpreted in one of two ways: either as a pneumothorax, or as an obstructive emphysema due to partial occlusion of the left main bronchus.

Usually with a spontaneous pneumothorax, the heart is displaced away from the lesion, but quite commonly, owing either to a fixed mediastinum or to the 